\title{
The Curious Case of Carles Puigdemont-The European Arrest Warrant as an Inadequate Means with Regard to Political Offenses
}

\author{
Julia König' ${ }^{1, *}$, Paulina Meichelbeck ${ }^{2, * *}$ and Miriam Puchta ${ }^{3, * * *}$ \\ ${ }^{1}$ Graduate Student of Law, Friedrich-Alexander University Erlangen-Nürnberg, Nürnberg, Germany, ${ }^{2}$ Chair of Civil Law, \\ Intellectual Property and Technology Law, Friedrich-Alexander University Erlangen-Nürnberg, Nürnberg, Germany and \\ ${ }^{3}$ Institute for German, European and Public International Law, Friedrich-Alexander University Erlangen-Nürnberg, \\ Nürnberg, Germany
}

Corresponding author: Julia König, Email: julia.koenig.grass@t-online.de

(Received 28 November 2019; revised 06 August 2020; accepted 17 December 2020)

\begin{abstract}
In contrast to traditional extradition law, the political offense exemption has been abolished within the framework of the European Arrest Warrant (EAW). Notwithstanding its overall success, the EAW does not constitute an adequate instrument with regard to political offenses. In light of the recent case of the former Catalan President, Carles Puigdemont, the abolition has proven to be too hasty and the justificatory force behind the principles of mutual trust and recognition is, with respect hereto, rather limited. The damage caused to these principles by upholding the exemption would be negligible, given the small number of casesPuigdemont being the first political offender requested under the aegis of the EAW. However, the potential benefits are substantial, given that the exemption provides for a higher level of human rights protection-analogous to the values of European Union (EU). Solely relying on the double criminality requirement in order to properly take into account the specificities of the Member States' legal systems essentially positions the judges at the forefront of where mutual trust and constitutional identity collide. Moreover, the exemption prevents states from intervening in other states' internal political conflicts, through the medium of criminal law.
\end{abstract}

Keywords: Law of the European Union; extradition law; European Arrest Warrant; EAW Framework Decision; political offense exemption; corruption; sedition; High Treason; Breach of Peace; Area of Freedom; Security and Justice; mutual trust; mutual recognition; Criminal Law; independence referendum; spiritual leader doctrine

\section{A. Introduction}

Brexit, rising nationalism, the refugee crisis, foreign threats such as terrorism, and the coronavirus pandemic have brought the European Union (EU) to a crossroads. The next few decades will show

*Julia König graduated with a degree in law from the Friedrich-Alexander University Erlangen-Nürnberg, Germany in January 2021 and will shortly be embarking on her legal traineeship at the Higher Regional Court in Nuremberg.

${ }^{* *}$ Paulina Meichelbeck is a student of law at the Friedrich-Alexander University Erlangen-Nürnberg, Germany, and a research assistant at the Chair of Civil Law, Intellectual Property, and Technology Law held by Professor Dr. Franz Hofmann, LL.M. (Cambridge).

${ }^{* * *}$ Miriam Puchta is currently studying French and German Law at the Friedrich-Alexander University Erlangen-Nürnberg, Germany. She also works at the university's Institute for German, European, and Public International Law and holds a Bachelor of Laws degree from the Université de Rennes I.

The authors wish to thank Dr. Kevin Pike and Professor Dr. Christoph Safferling for providing them with the opportunity to write this contribution to the German Law Journal and for their support throughout.

(C) The Author(s), 2021. Published by Cambridge University Press on behalf of the German Law Journal. This is an Open Access article, distributed under the terms of the Creative Commons Attribution licence (http://creativecommons.org/licenses/by/4.0/), which permits unrestricted re-use, distribution, and reproduction in any medium, provided the original work is properly cited. 
whether the Member States will, as a result of the prevailing issues, converge and collaborate more closely or whether the already existing rift within the EU will heighten, jeopardizing the EU's very existence. With respect to judicial cooperation, the millennium started promisingly-given the introduction of an Area of Freedom, Security, and Justice (AFSJ) in the Treaty of Amsterdam in May 1997, ${ }^{1}$ and the establishment of the European Arrest Warrant (EAW) five years later, strengthening the former third pillar. ${ }^{2}$ The EU appeared to be set on its path. Yet, in the past several years, numerous unexpected developments—-such as the legislative reforms in Poland's justice system and nationalist movements in several Member States-have emerged, questioning the image of Europe as the cradle of democracy. In particular, in the course of protests, images portraying the Spanish Prime Minister as a grand inquisitor were rolled out on the streets of Barcelona. ${ }^{3}$ These illustrated, with respect to the EU, the rather unusual case of someone being requested on the grounds of political activity. In light of the above-mentioned case of Puigdemont casting doubt on the EAW's efficiency, it became apparent that the EAW-previously a shining example of judicial cooperation-had become a cause for considerable headaches.

\section{B. The European Arrest Warrant}

\section{Implementation into German Law}

The general idea of the EAW was first publicly addressed at the Tampere European Council on October 15-16, 1999, with the creation of the Area of Freedom, Security and Justice (AFSJ). ${ }^{4}$ Because traditional forms of judicial cooperation were considered to be insufficient instruments for combatting the increase in cross-border criminality-following the abolition of border checks in 1995, as a result of the 1985 Schengen Agreement ${ }^{5}$ - the Council resolved to depart from the traditional extradition towards "a simple transfer of ... persons [fleeing from justice after having been finally sentenced].” In addition, the principle of mutual recognition of judicial decisions and judgments was recognized as the "cornerstone of judicial co-operation in . . . criminal matters within the Union."7 Built upon mutual trust and mutual confidence, the concept of mutual recognition of judicial decisions and judgments refers to the recognition and enforcement of one Member State's decisions by courts of another Member State, which are regarded as being

\footnotetext{
${ }^{1}$ Treaty of Amsterdam Amending the Treaty on European Union, the Treaties Establishing the European Communities and Certain Related Acts, Oct. 2, 1997, 1997 O.J. (C 340) 1.

${ }^{2}$ See Jan Löber, Die Ablehnung der Vollstreckung des Europäischen Haftbefehls: Ein Vergleich der GESETZLiCHEN GRUNDLAGEN UND PRAKTISCHEN ANWENDUNG ZWISCHEN SPANIEN UND DeUTSCHLAND 60, 72 (Mark Zöller ed., 2017).

${ }^{3}$ See Christoph Safferling, Spanische Machtspiele, mitten in Deutschland, SüDdeutSCHE ZeITUNG (Mar. 26, 2018, 12:40 PM), https://www.sueddeutsche.de/politik/verhaftung-von-carles-puigdemont-spanische-machtspiele-mitten-in-deutschland-1. 3921455.

${ }^{4}$ See Heiko Ahlbrecht, Freier Personenverkehr innerhalb der Europäischen Union in Auslieferungssache-die Umsetzung des Europäischen Haftbefehls in das deutsche Rechtshilferecht, 1 STRAFVERTEIDIGER 40, 41 (2005).

${ }^{5}$ Agreement Between the Governments of the States of the Benelux Economic Union, the Federal Republic of Germany and the French Republic on the Gradual Abolition of Checks at Their Common Borders, June 14, 1985, 2000 O.J. (L 239) 13

${ }^{6}$ See Presidency Conclusions, Tampere European Council (Oct. 15-16, 1999), para. 35 [hereinafter Tampere Presidency Conclusions]; Sarah Haggenmüller, Der Europäische Haftbefehl und die VerhältnismäßigKeIt SEINER ANWENDUNG In Der Praxis 61 (Wilfried Fiedler et al. eds., 2018); Libor Klimek, Mutual Recognition of Judicial Decisions in European Criminal Law 105 (2017) [hereinafter Klimek, Mutual Recognition]; André Klip, European Criminal LAW: An Integrative Approach 141 (3d ed. 2016).

${ }^{7}$ See Tampere Presidency Conclusions, supra note 6, at para. 33; Nicola Vennemann, The European Arrest Warrant and Its Human Rights Implications, 63 ZAÖRV 103, 106-07 (2003); Helmut Satzger, Is Mutual Recognition a Viable General Path for Cooperation?, 10 NEW J. EUR. CRIM. L. 47 (2019); Anne Weyembergh, Critical Assessment of the Existing European Arrest Warrant Framework Decision, 6 Eur. Added VAlue Assesment: Eur. Arrest Warrant 1 (2013).
} 
equivalent to one's own decisions, without further review or recognition proceedings. ${ }^{8}$ As the first concrete measure to implement the principle of mutual recognition of judicial decisions in the EU, the EAW was speedily adopted as a framework decision-pursuant to Article 31(1)(a-b) of the Treaty on the European Union ${ }^{9}$ (TEU) (old version) in conjunction with Article 34 (2)(b) TEU (old version) by the European Council on June 13, 2002 ${ }^{10}$ (EAW Framework Decision) - in the aftermath of the $9 / 11$ attacks in the United States. ${ }^{11}$ Aimed at simplifying and accelerating the lengthy extradition procedures within the EU, the EAW was designed to enhance and render more effective cooperation in criminal matters. ${ }^{12}$ Pursuant to Article 1(1) of the EAW Framework Decision, an EAW constitutes a judicial decision issued by a Member State with a view to arrest and surrender by another Member State a requested person, for the purposes of conducting a criminal prosecution, or executing a custodial sentence or detention order. In accordance with Article 2(1) of the EAW Framework Decision, its scope encompasses acts punishable by the law of the issuing Member State with a custodial sentence or a detention order for a maximum period of at least twelve months or-where a sentence has been passed or a detention order has been made-for sentences of at least four months.

Due to its adoption as a framework decision, the EAW required implementation into national legislation. ${ }^{13}$ Germany complied with this obligation through the enactment of the Europäisches Haftbefehlsgesetz ${ }^{14}$ (EuHbG) in 2004, which was held to be unconstitutional by the German Federal Constitutional Court and, therefore, was readopted in 2006, following a modification to the offending provisions. ${ }^{15}$ The EuHbG $2006^{16}$ does not constitute an autonomous act, but rather complements the already existing Act on International Cooperation in Criminal Matters of $1982^{17}$ (Gesetz über die internationale Rechtshilfe in Strafsachen; IRG) by incorporating $\$ \$ 78$ et seq. as a new Part VIII. ${ }^{18}$

Replacing all previous extradition agreements between EU Member States, the EAW Framework Decision deviates from the traditional system of extradition by abolishing its twostage structure - comprised of a judicial decision, and a governmental, and thus political, decision. Henceforth it solely requires a judicial procedure. ${ }^{19}$ Apart from maintaining the requirement of a granting procedure, the German EuHbG continues to apply the traditional terms of "extradition"

\footnotetext{
${ }^{8}$ See KlimeK, Mutual Recognition, supra note 6, at 105; Klip, supra note 6, at 400; Satzger, supra note 7, at 45-46; Landro Mancano, Mutual Recognition in Criminal Matters, Deprivation of Liberty and the Principle of Proportionality, 25 MAASTRICHT J. EUR. \& COMP. L. 722 (2018).

${ }^{9}$ Treaty on European Union, Feb. 7, 1992, 1992 O.J. (C 191) 1.

${ }^{10}$ Council Framework Decision 2002/584/JHA of June 13, 2002 on the European Arrest Warrant and the Surrender Procedures Between Member States, 2002 O.J. (L 190) 1 [hereinafter EAW Framework Decision].

${ }^{11}$ See Libor KlimeK, European Arrest Warrant 22-23 (2015) [hereinafter KLIMEK, EAW]; HaggenMüller, supra note 6, at 66, 87; Weyembergh, supra note 7, at 2; Anne Pieter van der Mei, The European Arrest Warrant System: Recent Developments in the Case Law of the Court of Justice, MAAstricht J. Eur. \& COMP. L. 883 (2017).

${ }^{12}$ See KlimeK, EAW, supra note 11, at 22-23; Vennemann, supra note 7, at 103; Mancano, supra note 8, at 722.

${ }^{13}$ See HaggenMülLER, supra note 6 , at $66,87$.

${ }^{14}$ Gesetz zur Umsetzung des Rahmenbeschlusses über den Europäischen Haftbefehl und die Übergabeverfahren zwischen den Mitgliedstaaten der Europäischen Union, Europäisches Haftbefehlsgesetz [EuHbG] [European Arrest Warrant Act], July 21, 2004, Bundesgesetzblatt, Teil I [BGBL I] at 381748 (Ger.).

${ }^{15} \mathrm{See}$ Eckhart von Bubnoff, Das EuropäIsche Haftbefehlsgesetz 2006: ErgänZung Zum Leitfaden "Der Europäische Haftbefehl”; Auslieferung und Neuerungen des Gemeinschaftsinstruments 5 (2007).

${ }^{16}$ Gesetz zur Umsetzung des Rahmenbeschlusses über den Europäischen Haftbefehl und die Übergabeverfahren zwischen den Mitgliedstaaten der Europäischen Union, Europäisches Haftbefehlsgesetz [EuHbG] [European Arrest Warrant Act], July 20, 2006, Bundesgesetzblatt, Teil I [BGBL I] at 361721 (Ger.).

${ }^{17}$ Gesetz über die internationale Rechtshilfe in Strafsachen [IRG] [Act on International Mutual Assistance in Criminal Matters], Dec. 23, 1982, Bundesgesetzblatt, Teil I [BGBL I] at 57 2071, translation at https://www.gesetze-im-internet. de/englisch_irg/index.html (Ger.).

${ }^{18}$ See LÖBER, supra note 2, at 160-61.

${ }^{19}$ See EAW Framework Decision, supra note 10, art. 1(1); KLIMEK, EAW, supra note 11, at 28; HAGGENMÜLLER, supra note 6 , at 80 ; van der Mei, supra note 11 , at 886 .
} 
(Auslieferung), "requesting state" (ersuchender Staat), and "requested state" (ersuchter Staat)_ instead of the newly introduced terms of "surrender" (Übergabe), "issuing state" (Ausstellungsstaat), and "executing state" (Vollstreckungsstaat). ${ }^{20}$ In addition to the simplified extradition procedure, the double criminality requirement-see below at Subsection C(I)(1.1) -is subject to restrictions, as it is not verified with regard to thirty-two categories of offenses listed in Article 2(2) of the EAW Framework Decision, provided that these offenses are punishable in the issuing Member State by a custodial sentence or a detention order of a maximum period of at least three years. ${ }^{21}$ Likewise, the potential grounds for refusal of execution are limited and exhaustively listed in Articles 3, 4, and 4(a) of the EAW Framework Decision. ${ }^{22}$ The sole mandatory grounds for the non-execution of an EAW are amnesty, the principle of ne bis in idem, and the age of the requested person-that is, minors. ${ }^{23}$

\section{A Successful Instrument of Cross-border Judicial Cooperation}

Despite initial skepticism towards the establishment of the $\mathrm{EAW}^{24}$ —as well as the more recent issues of, for instance, the surrender of a Member State's own nationals ${ }^{25}$ or decisions in absentia $^{26}$ - the EAW has, to date, proven to be successful in the vast majority of cases. Statistics show the issuance of 133,977 EAWs in total, from 2005 to 2015, of which 37,139 were executed. ${ }^{27}$ In particular, with regard to offenses such as theft and corruption-the most common categories of offenses for which EAWs were issued ${ }^{28}$ — as well as serious crimes that are commonly recognized throughout Europe, the EAW has justified its existence because such offenses require effective judicial cooperation. ${ }^{29}$ The EAW's stringent, absolute maximum ninety-day time limit has resulted in a significant acceleration of the previously lengthy extradition process - which, nowadays, lasts a mere forty-three days on average, as opposed to more than a year prior to the EAW's adoption. ${ }^{30}$ Compared to the previous provisions, the EAW contributes to a more effective attack on cross-border criminality and harmonizes the extradition process. ${ }^{31}$

\section{The European Arrest Warrant in Light of the Puigdemont Case}

Notwithstanding its overall success, the EAW's approach to extraditions for political offenses appears highly problematic in light of the recent case of the former Catalan President, Carles Puigdemont. As one of seventeen semi-autonomous regions in Spain, Catalonia is known for its pronounced regionalism, which stretches back more than 300 years and has fostered a strong

\footnotetext{
${ }^{20}$ See LÖBER, supra note 2, at 161. For convenience only, the old terminology "extradition," "requesting State," and "requested State" will be used in the following.

${ }^{21} \mathrm{See}$ Commission Notice of Sept. 28, 2017, Handbook on How to Issue and Execute a European Arrest Warrant, 2017 O.J. (C 335) 1, 13 [hereinafter EAW Handbook]; van der Mei, supra note 11, at 896.

${ }^{22}$ See EAW Handbook, supra note 21, at 13; van der Mei, supra note 11, at 891.

${ }^{23}$ See EAW Handbook, supra note 21, at 41-42.

${ }^{24}$ See Bernd Schünemann, Die parlamentarische Gesetzgebung als Lakai von Brüssel? Zum Entwurf des Europäischen Haftbefehlsgesetztes, 9 STRAFVERTEIDIGER 531, 532 (2003).

${ }^{25}$ See also KLIMEK, EAW, supra note 11, at 247-52.

${ }^{26}$ See also KLIMEK, EAW, supra note 11, at 243-47. For further points of criticism, see Weyembergh, supra note 7, at 4; European Criminal Policy Initiative, A Manifesto on European Criminal Procedure Law, 11 ZEITSCHRIFT FÜR INTERNATIONALE StrafrechstdogmatiK 430 (2013); van der Mei, supra note 11, at 883-84; John Vervaele, European Criminal Justice in the European and Global Context, 10 NEW J. EUR. CRIM. L. 12 (2019).

${ }^{27}$ See Commission Staff Working Document, Replies to Questionnaire on Quantitative Information on the Practical Operation of the European Arrest Warrant, Annex III, COM (2019) 318 final (Aug. 28, 2019) [hereinafter Commission Staff Working Document].

${ }^{28}$ See Commission Staff Working Document, supra note 27, at 4.

${ }^{29}$ See also Safferling, supra note 3.

${ }^{30}$ See KlimeK, MutUal ReCOGnition, supra note 6, at 244; Vennemann, supra note 7, at 109.

${ }^{31}$ See HAGgENMÜLLER, supra note 6, at 376.
} 
independence movement. ${ }^{32}$ Against this background, an independence referendum-led by Puigdemont-was conducted on October 1, 2017, with a reported turnout of approximately $43 \%$ and a result of $90 \%$ in favor of independence. ${ }^{33}$ The referendum was declared unconstitutional and therefore rendered void by the Spanish Federal Constitutional Court, as the Spanish Constitution does not provide for referenda on the independence of a semi-autonomous region. ${ }^{34}$ Upon Catalonia's declaration of independence on October 27, 2017, the Spanish government dissolved the Catalan parliament and announced new elections-applying Article 155 of the Spanish Constitution ${ }^{35}$ for the first time since it had come into force. ${ }^{36}$ This provision enables the Spanish parliament to deprive a region of its autonomous rights. ${ }^{37}$ As a result of the charges of rebellion, sedition, and misuse of public funds proffered against Puigdemont and several members of his deposed cabinet on October 30, 2017, Puigdemont fled to Belgium to avoid arrest. ${ }^{38}$ Consequently, an EAW was issued on November 2, 2017 but withdrawn approximately a month later due to a discrepancy between Spanish and Belgian law which might have restricted the extradition charges and, therefore, may have led to different charges compared to those the other leaders of the independence movement-who were on trial in Spain-were to face. ${ }^{39}$ Nevertheless, after the EAW was reactivated on March 23, 2017, Puigdemont was detained near Schleswig, Germany two days later, on his return from Finland to Belgium. ${ }^{40}$

\section{Decisions of the OLG Schleswig-Holstein}

\section{Decision of April 5, 2018}

On April 5, 2018, the First Senate for Criminal Matters of the Higher Regional Court of SchleswigHolstein (Oberlandesgericht Schleswig-Holstein; OLG) passed its first decision concerning Puigdemont's extradition to Spain. ${ }^{41}$ Summarily, the court ordered extradition detention-pursuant to $\$ \$ 15(1)$ No. 1 and 17(1) IRG-but stayed the execution of the extradition arrest warrant under certain conditions, in accordance with $\$ 25(2)$ IRG and in conjunction with $\$ 116(1)$ s. 2

\footnotetext{
${ }^{32}$ See Hans-Jürgen Puhle, Trajectories of Catalan Nationalism and Its Present Discontents, in CATALONIA IN SPAIN \& Europe: Is There a WAy to IndePENDENCE? 13, 13-26 (Klaus-Jürgen Nagel \& Stephan Rixen eds., 1st ed. 2015).

${ }^{33}$ See Isa Soares, Vasco Cotovio \& Hilary Clarke, Catalonia Referendum Result Plunges Spain into Political Crisis, CNN (Oct. 2, 2017, 1:57 PM), https://edition.cnn.com/2017/10/01/europe/catalonia-spain-independence-referendum-result/index.html; Luigi Foffani, The Case Puigdemont: The Stress-Test of the European Arrest Warrant, 8 Eur. CrIM. L. ReV. 197 (2018).

${ }^{34}$ See Sam Jones, Can Catalonia Declare Independence from Spain?, GuARDIAN (Oct. 4, 2017, 5:35 AM), https://www. theguardian.com/world/2017/oct/04/can-catalonia-declare-independence-from-spain.

${ }^{35}$ Constitución EsPañola, B.O.E. n. 311, Dec. 29, 1978, art. 155, https://www.boe.es/legislacion/documentos/ ConstitucionINGLES.pdf (Spain).

${ }^{36}$ See Sam Jones, Stephen Burgen \& Emma Graham-Harrison, Spain Dissolves Catalan Parliament and Calls Fresh Elections, GUARDIAN (Oct. 28, 2017, 5:56 AM), https://www.theguardian.com/world/2017/oct/27/spanish-pm-mariano-rajoy-askssenate-powers-dismiss-catalonia-president; Foffani, supra note 33, at 197.

${ }^{37}$ See Jones, Burgen \& Graham-Harrison, supra note 36.

${ }^{38}$ See Sam Jones, Catalan Leaders Facing Rebellion Charges Flee to Belgium, GuARDIAN (Oct. 31, 2017, 5:37 AM), https:// www.theguardian.com/world/2017/oct/30/spanish-prosecutor-calls-for-rebellion-charges-against-catalan-leaders.

${ }^{39}$ See Stephen Burgen \& Daniel Boffey, Spanish Judge Withdraws Arrest Warrant for Carles Puigdemont, Guardian (Dec. 5, 2017, 10:00 AM), https://www.theguardian.com/world/2017/dec/05/spanish-judge-withdraws-arrest-warrants-for-carlespuigdemont.

${ }^{40}$ See Stephen Burgen \& Philip Oltermann, Catalan Leader Carles Puigdemont Held by German Police, GUARDIAN (Mar. 25, 2018, 7:49 AM), https://www.theguardian.com/world/2018/mar/25/catalan-leader-carles-puigdemont-held-by-germanpolice; Lorena Bachmaier, European Arrest Warrant, Double Criminality and Mutual Recognition: A Much Debated Case, 8 Eur. Crim. L. Rev. 153 (2018); Foffani, supra note 33, at 196.

${ }^{41}$ Oberlandesgericht Schleswig-Holstein [OLG Schleswig-Holstein] [Higher Regional Court of Schleswig-Holstein] Apr. 5, 2018, 1 Ausl (A) 18/18 (20/18), Neue JuRISTISCHE WOCHENSCHRIFT [NJW] 1699, 2018 (Ger.) [hereinafter Judgment of Apr. 5, 2018 .
} 
No. 4 of the German Code of Criminal Procedure (Strafprozessordnung; StPO), ${ }^{42}$ ordering a release on bail set at $€ 75,000$. The judges held that a surrender of the requested person for the crime of rebellion ${ }^{43}$ under the EAW was inadmissible $a b$ initio and thus did not constitute grounds for extradition detention pursuant to $\$ 15(2)$ IRG ${ }^{44}$ Contrarily, the extradition for corruption-more specifically, the embezzlement of public funds, was not declared inadmissible $a b$ initio, but was subjected to further review by the OLG due to the insufficiency of the information submitted by the Spanish authorities in accordance with $\$ 83 a(1)$ No. 5 IRG. $^{45}$

\section{Decision of July 12, 2018}

On July 12, 2018, the OLG rendered its second — and final—decision in the matter, ${ }^{46}$ notably, after failing to meet the deadline of sixty days set by Article 17(3) of the EAW Framework Decision and $\$ 83 \mathrm{c}(1)$ IRG. In the following sections, further explanations, concretizations, and elaborationsregarding 1) the refusal to surrender for the offense of rebellion and 2) the Court's ultimate decision concerning a surrender for the offense of corruption, contained in its decision of July 12, 2018 -will be addressed, with a stronger focus on the legal and factual issues pertaining to the charge of rebellion and its "political" character.

\section{Surrender for Rebellion}

First, the OLG upheld its decision of April 5, 2018 with respect to the offense of rebellion, denying Puigdemont's surrender to Spain.

\subsection{Verification of Double Criminality}

The ruling commences with an extensive assessment of the double criminality of the underlying acts. This requirement — an exception to the general rule of mutual recognition ${ }^{47}$ — provides that the requested state only extradite if the underlying offense is penalized under the law of both the requesting state and the requested state, and has long been a key feature of international extradition law. ${ }^{48}$ With the EAW Framework Decision, the EU Member States decided to partially substitute this system - traditionally based on the reciprocity of criminalized behavior ${ }^{49}$ — by introducing a "softened double criminality requirement." 50

Rebellion, as referred to under the EAW in question-or, for that matter, similar offenses such as treason and sedition-is not listed under Article 2(2) of the EAW Framework Decision.

\footnotetext{
${ }^{42}$ Strafprozessordnung [StPO] [CODE OF Criminal Procedure], $\$ 116$, para. 1, sentence 2, translation at http://www. gesetze-im-internet.de/englisch_stpo/index.html (Ger.).

${ }^{43}$ In the EAW of March 23, 2018, the Supreme Court of Spain (Tribunal Supremo) mentioned the offense of "rebellion" along with "sedition," the latter of which remains unmentioned in both OLG decisions. This is probably due to its similarity to rebellion, the lack of a one-to-one correspondence under German law, and the extensive review of all possible offenses of the StGB.

${ }^{44}$ See Bachmaier, supra note 40, at 153; Foffani, supra note 33, at 196.

${ }^{45}$ According to the OLG, the EAW of March 23, 2018 was not issued in accordance with $\$ 83 a(1)$ Nr. 5 IRG, for want of a detailed description concerning the circumstances of the alleged crime and the concrete allegations against Puigdemont. See Judgment of Apr. 5, 2018 at para. 43. The necessary supplementary information was requested to allow the court to reach a decision pursuant to $\$ 30$ (1) IRG, Article 15 (2) of the EAW Framework Decision. See Foffani, supra note 33, at 196.

${ }^{46}$ Oberlandesgericht Schleswig-Holstein [OLG Schleswig-Holstein] [Higher Regional Court of Schleswig-Holstein] July 12, 2018, 1 Ausl (A) 18/18 (20/18), Neue JuRISTISCHE WochEnsCHRIFT [NJW] 93, 2019 (Ger.) [hereinafter Judgment of July 12, 2018].

${ }^{47}$ See Florentino-Gregorio Ruiz Yamuza, CJEU Case Law on Double Criminality. The Grundza-Piotrowski Paradox?, 19 ERA FORUM 465, 470-71 (2019).

${ }^{48}$ See KLIMEK, EAW, supra note 11 , at 81.

${ }^{49}$ See Geoff Gilbert, Responding to International Crime 74 (2006).

${ }^{50}$ KLIMEK, EAW, supra note 11, at 317 . For notes on CJEU jurisprudence regarding the double criminality requirement and the interpretative options at hand, see Yamuza, supra note 47 , at $470-75$.
} 
Pursuant to Articles 2(4) and 4(1) of the EAW Framework Decision, and in conjunction with $₫ 81$ No. 4 IRG, the lack of double criminality is considered a ground for optional non-execution of the EAW. ${ }^{51}$ In the present case, the OLG argued that in accordance with $₫ 3$ (1) IRG, an extradition may be deemed admissible only if the act the requested person is accused of constitutes mutatis mutandis, an offense under German law, ${ }^{52}$ otherwise compelling the executing judicial authority to refuse the execution of an EAW. ${ }^{53}$ Therefore, the case is assessed as if it had occurred in Germany, the offender was a German citizen, and German institutions had been parties to the case. The defendant's conduct would not be penalized under German law, so the case is reviewed as if the president of a German federal state (Bundesland) had attempted a secession. ${ }^{54}$ Intending to extensively assess all legal norms possibly applicable to the case, ${ }^{55}$ the OLG restricted its review to two legal norms contained within the German Criminal Code (Strafgesetzbuch; StGB): 1) Hochverrat gegen den Bund (High treason against Federation) pursuant to $\$ 81$ (1) StGB and, 2) Landfriedensbruch (Breach of Peace) in accordance with $₫ 125(1)$ StGB. ${ }^{56}$

\subsection{High Treason Against Federation}

With respect to $\$ 81$ (1) StGB, the OLG Schleswig-Holstein largely refers to its first decision and a judgment passed by the German Federal Court of Justice (Bundesgerichtshof; BGH) concerning violent protests accompanying the plans for an airport expansion in Frankfurt-am-Main-the "Startbahn West" case. ${ }^{57}$

In order to assume criminal liability, pursuant to $\$ 81$ (1) StGB, the accused must have undertaken to undermine the continued existence of the Federal Republic of Germany-No. 1-or to change the constitutional order based on the Basic Law (Grundgesetz; GG) of the Federal Republic of Germany-No. 2. Both the German regulation and the provision of "rebellion"-pursuant to Article 472 No. 5, 7 Spanish Penal Code (Codigo Penal), as adduced by the Tribunal Supremoprovide that the perpetrator has undertaken the alleged acts "by force" ("violentamente"), albeit that in the present case, the accused had attempted to legitimize the secession of Catalonia by democratic means, namely via a referendum.

According to the OLG, the force used during this event had, in any case, not attained the requisite dimension for culpability-pursuant to both $\$$ 81(1) StGB and Article 472 Codigo Penal. ${ }^{58}$ Under German criminal law, $\$ 81$ (1) StGB postulates a qualified level of force which, with respect to its intended effect, is adequate to coerce the state into agreeing to the demands of the perpetrators. As the OLG had already elaborated upon, in its decision of April 5, 2018, the terminology of $₫ 81$ (1) StGB is determined in

\footnotetext{
${ }^{51}$ See EAW Handbook, supra note 21, at 42.

${ }^{52}$ See Judgment of Apr. 5, 2018 at para. 19; see also GILBERT, supra note 49, at 101-111 (providing a detailed treatise on double criminality).

${ }^{53}$ In its judgment in Grundza, the CJEU clarified how double criminality shall be reviewed by the executing Member State: $[\mathrm{W}]$ hen assessing double criminality, the competent authority ... is required to verify whether the factual elements underlying the offence as reflected in the judgment handed down by the competent authority of the issuing State, would also, per se, be subject to a criminal penalty in the executing State if they were present in that State.

See ECJ, Case C-289/15, Grundza, ECLI:EU:C:2017:4 (Jan. 11, 2017), para. 38.

${ }^{54}$ See Judgment of Apr. 5, 2018 at paras. 20-22.

${ }^{55}$ The OLG does not provide an answer to the question whether the German laws applied to the case must be legally congruent with the Spanish ones or whether the application of any legal norm suffices to verify the double criminality. See Judgment of July 12, 2018 at para. 8.

${ }^{56}$ See STRAFGESETZBUCH [StGB] [PenAl CODE], $\$ \$ 81,125$, translation at http://www.gesetze-im-internet.de/englisch_stgb/ index.html (Ger.).

${ }^{57} \mathrm{See}$ Bundesgerichtshof [BGH] [Federal Court of Justice] Nov. 23, 1983, 32 ENTSCHEIDUNGEN DES BUNDESGERICHTSHOFS IN Strafsachen [BGHST] 165, 1983 (Ger.); see also Nikolaos Gazeas, Auslieferungsentscheidung nach spanischem Auslieferungsersuchen - Puigdemont, NEUE JURISTISCHE WOCHENSCHRIFT 1699 (2018) (providing a critical perspective on the comparability of the cases).

${ }^{58}$ See Judgment of July 12, 2018 at paras. 9-10.
} 
the same way as $₫ 105 \mathrm{StGB}$ —blackmailing constitutional organs (Nötigung von Verfassungsorganen)_ a regulation applied in the aforementioned judgment passed by the $\mathrm{BGH} .^{59}$

This heightened requirement, with respect to the degree of force used, is justified by the OLG as follows: First, in a democratic constitutional and political order, criminal law is obliged to be used restrictively with regard to political conflicts. Second, the state-as the target of force, with its administrative body of institutions-is comparably less easily affected and influenced by the use or threat of force than an individual. ${ }^{60}$

High treason is considered an "undertaking" (Unternehmen)—pursuant to $\$ 11$ (1) No. 6 StGB -and therefore, the acts committed by the accused do not actually have to succeed for culpability to arise in accordance with $\$ 81$ (1) StGB, bringing about a propensity towards prematurely criminalizing public discourse. The force used must indeed be sufficient for the perpetrator to succeed in compelling the constitutional organs to yield to his demands. A positive finding by the Court with respect to this qualification is a prerequisite for culpability, pursuant to $\$ 81$ (1) StGB. As a preliminary question, a normative evaluation of whether the force could potentially succeed must be undertaken (normative Tatbestandsvoraussetzung). ${ }^{61}$

The OLG held that the constitutional order of the Spanish State did not appear unduly distraught by the isolated incidents, which occurred in front of 17 out of 2,259 polling stations on the day of the referendum-October 1, 2017. The Court was unaware of any rioting, arson, or similar criminal actions which could have led to a violent overthrowing of the Spanish government. According to the supplementary information submitted by the Spanish authorities on April 26, 2018, a rampage had indeed been caused by, inter alia, large-scale demonstrations and blockages of road and rail traffic. Nevertheless, without any direct temporal or causal correlation to the referendum itself, this was not sufficient to prove the personal criminal liability of Puigdemont. Neither the alleged instructions directed towards the regional police, with the order to secure the referendum but without containing any orders to attack the national police or Guardia Civil, nor the supposedly superior numbers of the regional police officers in comparison to the national police ${ }^{62}$ are indicative of Puidgemont's culpability. Ultimately, the fact that the referendum-according to the perception of the accused-would not have directly led to the secession of Catalonia from Spain, but merely may have been a prelude to negotiations between both parties, also supports the Court's decision to reject the existence of double criminality pursuant to $\$ 81(1)$ StGB.

\subsection{Breach of Peace}

Second, the court scrutinized whether the alleged acts constituted a breach of peace pursuant to $\$$ 125(1) StGB. ${ }^{63}$ Considering that Puigdemont was not present at the public displays of violence surrounding the referendum, the OLG examined whether he could be deemed responsible as a "spiritual leader." Following the jurisdiction of the BGH, a person may be convicted of breach of peace as a joint offender in accordance with $\$ 25(2)$ StGB — even if they are not present at the location-as long as the force used against other persons or objects can be attributed to them

\footnotetext{
${ }^{59}$ See 32 BGHST 165 (170) (Ger.).

${ }^{60}$ See, e.g., Bundesgerichtshof [BGH] [Federal Court of Justice] May 6, 1954, 6 EnTSCHEIDUNGEN DES BundesGerichtSHOFS IN STRAFSACHEN [BGHST] 336 (340), 1954 (Ger.); Jun. 4, 1955, 8 ENTSCHEIDUNGEN DES Bundesgerichtshofs in STRAFSACHEN [BGHST] 102 (106), 1955 (Ger.).

${ }^{61}$ See 32 BGHST 165 (174) (Ger.); see also Judgment of July 12, 2018 at para. 11.

${ }^{62}$ According to the Spanish authorities, on the day of the referendum, there was a superiority of 17,000 regional police officers-compared to 6,000 national police officers. However, the numbers appear to be incorrect, with only 7,000 regional police officers on duty on October 1, 2017. See Judgment of July 12, 2018 at para. 13.

${ }^{63}$ This was first touched upon in a decision rendered by the OLG on May 22, 2018. When assessing whether the organizer behind a mega event has committed an offense, the court first takes the legality and constitutionality of the event into account. As the referendum of October 1, 2017 was declared unconstitutional by the Spanish Constitutional Court-through provisional order-the OLG ultimately shares the view that the event itself was in fact illegal. See Judgment of July 12, 2018 at paras. 13-15.
} 
in accordance with the general principles of the StGB. ${ }^{64}$ This "spiritual leader" doctrine, however, has been subject to criticism and remains controversial with respect to the requirements for participation, pursuant to $\$ 125$ (1) StGB. ${ }^{65}$ The letter of the law here is unclear and vague, resulting in both the need for interpretation by the courts and the risk of violating the rule of law. ${ }^{66}$ In the aftermath of the BGH decision, the respective case was even brought before the Federal Constitutional Court (Bundesverfassungsgericht; BVerfG). Notably, the court only dismissed the case with respect to violations of the appellant's freedom of expression and freedom of assembly-pursuant to Articles 5(1) s. 1 and 8(1) GG-following an evenly split vote. ${ }^{67}$

In the present case, however, the accused was found to have had neither the requisite mens rea to satisfy the conditions of $\$ 25 \mathrm{StGB}$, due to a lack of intent (Tatwille) - as his reiterated statements emphasizing the necessity for a peaceful approach to the Catalonian independence process suggested-nor would he have been able to influence the events, due to the lack of the requisite actual-that is, physical—control (Tatherrschaft). ${ }^{68}$ Ultimately, the OLG did not consider Puigdemont a planner, organizer, nor even a supporter of concrete foreseeable acts of violence and, therefore, declared a surrender on the grounds of rebellion to be inadmissible. ${ }^{69}$

\section{Surrender for Corruption}

As far as Puigdemont's surrender for "corruption" on the grounds of the embezzlement of public funds, an extradition was declared admissible by the OLG. In its considerations, the court first referred to its decision of April 5, 2018, in which the category of corruption-listed in Article 2(2) of the EAW Framework Decision-and the subsumption of embezzlement thereunder were scrutinized..$^{70}$ Without examining the double criminality, the court simply reviewed the justifiability of classifying the acts as corruption-without undertaking an in-depth analysis of the termand, at most, the plausibility of the course of events. ${ }^{71}$

The OLG recognized the complex nature of the concept of corruption and lack of a standardized definition. Corruption, as a global problem, takes many different forms. Thus, naturally, approaches to combat corruption differ globally. International anti-corruption efforts most prominently include the United Nations Convention against Corruption (UNCAC), ${ }^{72}$ the

\footnotetext{
${ }^{64}$ See 32 BGHST 165 (178) (Ger.).

${ }^{65}$ The "Startbahn West" decision-or "Schubart" case, see supra note 57-was merely the starting point of lengthy proceedings against the accused. With respect to this excess length, the BGH passed another decision in the matter almost ten years later. See Bundesgerichtshof [BGH] [Federal Court of Justice] Jan. 22, 1992, 3 StR 440/91, NeUE ZEITSCHRIFT FÜR STRAFRECHT [NSTZ] 229, 1992 (Ger.).

${ }^{66}$ See JÜrgen SCHÄFer, MÜnChener Kommentar ZUM StGB $\$ 125$ paras. 28-32 (3d ed. 2017); Matthias Krauß, 5 StGB LEIPZIGER Kommentar $\$ 125$ paras. 70-71 (12th ed. 2009); Maria-Katharina Meyer, Beteiligung am Landfriedensbruch (\$ 125 Abs. 1 1. und 2. Variante StGB) und Teilnahme zum Landfriedensbruch (\$125 Abs. 1 1. und 2. Variante in Verbindung mit $\$ \$$ 26, 27, 28 Abs. 1 StGB), in Goltdammer's ARCHIV FÜr Strafrecht 459 (2000).

${ }^{67}$ See Bundesverfassungsgericht [BVerfG] [Federal Constitutional Court] June 26, 1990, 1 BvR 776/84, NEUE JURISTISCHE WOCHENSCHRIFT [NJW] 91, 1991 (Ger.).

${ }^{68}$ See Judgment of July 12,2018 at paras. 15-17.

${ }^{69}$ As noted by Luigi Foffani, the charge of rebellion brought against Puigdemont by the Tribunal Supremo is less than convincing, based on Spanish law as well. See Foffani, supra note 33, at 197-99.

${ }^{70}$ Generally, the requesting State is competent to subsume the alleged actions under one of the categories of Article 2(2) of the EAW Framework Decision, in accordance with its own estimation. Should such a classification appear arbitrary and licentious, and not comply with the basic facts of the case, it becomes non-binding for the requested State. The OLG does not recognize any of these points as valid. Both corruption and embezzlement are characterized by the abuse of powers from the position of a person appointed for public office. Respecting the basis and idea of a joint European area of justice, nationally defined terminology and categories cannot be binding in this context. See Judgment of July 12, 2018 at paras. 17-18.

${ }^{71}$ See Oberlandesgericht Karlsruhe [OLG Karlsruhe] [Higher Regional Court of Karlsruhe] Mar. 13, 2007, 1 AK 28/06, Neue Zeitschrift FÜr Strafrecht RechtSPrechungs-Report [NStZ-RR] 376, 2007 (Ger.).

${ }^{72}$ G.A. Res. 58/4, 2003 United Nations Convention Against Corruption (Oct. 31, 2003).
} 
Council of Europe Group of States against Corruption (GRECO), ${ }^{73}$ and EU policies and legislation — such as the 1997 Convention on Fighting Corruption Involving Officials of the EU or Officials of Member States. ${ }^{74}$ Notably, the UNCAC does not provide a definition of corruption, but rather requires or encourages the Convention's parties to criminalize specific acts-such as the misuse of public funds - taking into account the various forms in which corruption may appear in different countries all around the globe. In this respect, the OLG's subsumption of the offense of misuse of public funds under "corruption" — as listed by Article 2(2) of the EAW Framework Decision-was subject to some criticism, as the scope of the offense under the Framework Decision-which provides a basis for concrete intrusive measures in the form of an EAW-calls for a more restrictive interpretation than a UN Convention adopted with the general political intent to fight corruption in the broadest sense. ${ }^{75}$ Overall, however, in spite of the ambiguity and lack of clarity regarding the term corruption, the EU Member States have-according to the court's view-come to the agreement that certain offenses are indeed essentially comparable, by adopting the catalog of offenses in Article 2(2) of the EAW Framework Decision. ${ }^{76}$

Notwithstanding the partial inconsistency of the extensive footage subsequently filed by the Spanish authorities, ${ }^{77}$ the description of events issued by the Spanish court to the OLG appears logical and convincing, with Puigdemont naturally planning to finance the statewide but uncon-

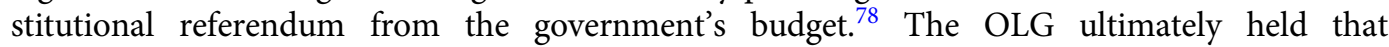
Puigdemont could be surrendered for corruption, subject only to a grant of approval by the Prosecutor General (Generalstaatsanwalt).

In the aftermath of the Puigdemont case, however, nine other Catalan separatist leaders were convicted of sedition and sentenced to between nine and thirteen years in prison by the Tribunal Supremo on October 14, 2019. ${ }^{79}$

\section{The Political Offense Exemption}

With regard to the major political importance and sensitivity of the Puigdemont case, the OLG approached the issues of extradition on the grounds of a political offense and political prosecution in both the decisions of April 5, 2018 and July 12, 2018 ${ }^{80}$ General German extradition law prohibits extradition on the grounds of a political offense, pursuant to $₫ 6$ (1) IRG. This "political offense exemption" is a principle developed by international extradition law; however, its perception in the European context has changed significantly over the past few decades. ${ }^{81}$

\footnotetext{
${ }^{73}$ GRECO was established in 1999 by the Council of Europe to monitor compliance with the Council's anti-corruption standard. Currently, GRECO comprises fifty member states-forty-eight European States, Kazakhstan, and the United States of America. See Group of States Against Corruption, CouncIL EuR., https://www.coe.int/en/web/greco (last visited Jan. 28, 2021).

${ }^{74}$ Convention Drawn Up on the Basis of Article K.3 (2) (c) of the Treaty on European Union on the Fight Against Corruption Involving Officials of the European Communities or Officials of Member States of the European Union, June 25, 1997, 1997 O.J. (C 195) 2 [hereinafter Treaty of European Union on the Fight Against Corruption].

${ }^{75}$ See Foffani, supra note 33, at 199.

${ }^{76}$ See Judgment of July 12, 2018 at para. 51.

${ }^{77} \mathrm{An}$ inconsistency in describing the circumstances of the case would lead only to the discontinuation of the surrender procedure, if the relevant parts of the submission needed to be ascertained or determined from a set of disclosures "like mosaics." Oberlandesgericht Celle [OLG Celle] [Higher Regional Court of Celle] May 28, 2009, 1 ARs 21/09, NeUE ZEITSCHRIFT FÜr STRAFRECHT RECHTSPREChUNGS-REPORT [NSTZ-RR] 313, 2009 (Ger.).

${ }^{78}$ See Judgment of July 12, 2018 at para. 18.

${ }^{79}$ See Violent Clashes Erupt as Spanish Court Jails Catalonia Leaders, BBC NEws (Oct. 14, 2019), https://www.bbc.com/ news/world-europe-49974289?fbclid=IwAR35V1G6N0EZzRHQEnodKr_tMB6w4KfXeliTl-LFgckdegIrLmXtkAVrGNs.

${ }^{80}$ See Judgment of Apr. 5, 2018 at paras. 45-49; see also Judgment of July 12, 2018 at paras. 20-21.

${ }^{81}$ See Hans Schultz, Habent sua fata delicta, Bemerkungen zum politischen Delikt im Auslieferungsrecht, in FESTSCHRIFT FÜR Hans Huber, 623, 623 et seq. (1981).
} 


\section{History and Considerations Behind the Exemption's Introduction}

Historically speaking, the idea that having committed a political offense warrants different treatment in extradition procedures is a fairly new one. ${ }^{82}$ Until the beginning of the nineteenth century, political offenses were one of the main grounds for extradition among European states. ${ }^{83}$ This phenomenon can be explained with reference to the European monarchies at the time having a common interest in preserving their respective political regimes. ${ }^{84}$

It was the civil revolutions and liberalism which gave birth to the concept of the political offense exemption. During the rise of democracy, liberal states wished to protect those who had fought to establish a liberal order. ${ }^{85}$

Though moral considerations - guided by sympathy for liberal movements and their advocates -were the initial trigger for the exemption, ${ }^{86}$ these considerations have always been overshadowed by the states' interests. ${ }^{87}$ According to the majority of legal scholars, this concept was inspired by the states' desire "to remain aloof from the internal affairs of the requesting state." 88 With regard to the principles of sovereignty and equality of all states under international law, the requested state refrains from intervening in an internal political conflict of the requesting state because any intervention would compel it to politically evaluate the parties to the conflict. ${ }^{89}$

Nonetheless, not extraditing constitutes, in some ways, just as much of an intervention in the requesting state's internal affairs and often implies a judgment on the impartiality of its judiciary. ${ }^{90}$ Thus, some commentators consider the exemption a tool of political opportunity which protects the requested state from having to extradite against its own interests. ${ }^{91}$ Factors employed to substantiate the inopportunity of extradition can be a perceived lack of danger emanating from the perpetrator and a given state's own interest in political change in the requesting state. ${ }^{92}$ For von Weber, the exemption is an expression of the competition of the states: Where every state is each other's potential enemy in war, it is more opportune not to extradite. ${ }^{93}$ Thus, the exemption grants the states a loophole to refuse extradition when deemed inopportune, sometimes concealing a political will behind a judicial decision. ${ }^{94}$

Another understanding of the exemption is that it has evolved into a principle of law-its function being to force the requested state to consider whether there are compelling reasons to risk a

\footnotetext{
${ }^{82}$ See Julia Jansson, Terrorism, Criminal Law and Politics 71-77 (2020); David Sadoff, Bringing International Fugitives to Justice 201 (2016); JoAchim Vogel, Grützner/Pötz/Kreß InTERnationaler Rechtshilfeverkehr in STRAFSACHEN $\$ 6$ para. 6 (Claus Kreß ed., 2009).

${ }^{83}$ See SAdOFF, supra note 82, at 131-32, 201; Klaus SCHWAIgHOFER, AUSLIEFERUNG UND INTERNATIONALES STRAFRECHT 108 (1988).

${ }^{84}$ See Torsten Stein, Das "politische Delikt" im Auslieferungsrecht / Anmerkung zu den Pohle-Entscheidungen des Athener Oberlandesgerichts vom 20.8.1976 und des Areopag vom 1.10.1976, EUROPÄISCHE GRUNDRECHT-ZEITSCHRIFT 59, 60 (1977).

${ }^{85}$ See JANSSON, supra note 82, at 71-77; SADOFF, supra note 82, at 201; VOGEL, supra note 82, at para. 6; Schultz, supra note 81 , at 624.

${ }^{86}$ See SCHWAIGHOFER, supra note 83, at 109.

${ }^{87}$ See Gilbert, supra note 49, at 194; JANSSON, supra note 82, at 76; WOLFGANG SCHOMbURG \& THOMAS HACKNER,

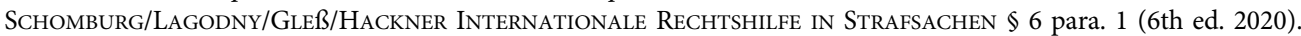

${ }^{88}$ See GILBERT, supra note 49, at 194; JANSSON, supra note 82, at 92; VOGEL, supra note 82, at para. 24; FrANK MEYER, Nomos Rechtshilferecht In Strafsachen $\$ 82$ para. 885 (Kai Ambos, Stefan König \& Peter Rackow eds., 2015);

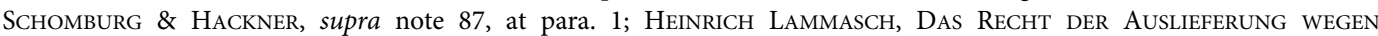
POLITISCHER VERBRECHEN 51 (1884).

${ }^{89}$ See JANSSON, supra note 82, at 92; SCHWAIGHOFER, supra note 83, at 109; VOGEL, supra note 82, at para. 24.

${ }^{90}$ See GILBERT, supra note 49, at 194; Dinah Shelton, The Relationship of International Human Rights Law and Humanitarian Law to the Political Offense Exception to Extradition, in NEW DiRECTIONS IN HuMAN RIGHTS 137 (Ellen Lutz ed., 1989); VOGEL, supra note 82, at para. 24.

${ }^{91}$ See Vogel, supra note 82, at 25; Hellmuth von Weber, Die Auslieferung bei politischen Delikten, in ERINNERUNGSGABE FÜr MAX GrÜnhut 161, 167 (Hilde Kaufmann ed., 1965); Daniel RohlfF, Der EuropÄISChe Haftbefehl 105 et seq. (2003).

${ }^{92}$ See SCHWAighofer, supra note 83, at 109; HeInRICH LAMMASCH, AusliefERUnGSPFliCht UND AsYlReCHT 227 (1878).

${ }^{93}$ See von Weber, supra note 91 , at 169.

${ }^{94}$ See GilberT, supra note 49, at 194.
} 
conflict with the requesting state by not extraditing. The decisive factor would then be whether the requesting state is worthy of protection. Therefore, $\$ 6(1)$ IRG has its independent value as a principle, protecting from prosecution in illiberal states which are thus not worthy of protection. ${ }^{95}$

\section{The Abolition of the Exemption Within the European Union}

Given the context of its introduction, one can easily retrace why, as liberalism spread throughout Europe, the political offense became less significant. ${ }^{96}$ After the horrors of World War II, grave and inhumane offenses were excluded. ${ }^{97}$ The exemption was further narrowed down after being abused by civil war criminals and terrorists, which had led states to start perceiving it as an obstacle to international justice. ${ }^{98}$

Thus, the 1996 EU Convention on Extradition Between Member States first introduced the idea of abolishing the political offense within the EU, even if it was possible to partially maintain it through notification. ${ }^{99}$

This evolution reached its logical conclusion with the introduction of the Framework Decision on the European Arrest Warrant, ${ }^{100}$ which does not list the political offense exemption among the grounds for non-execution or guarantees to be given in Articles 3-5 of the EAW Framework Decision. Thus, it effectively prevents Member States from resorting to this undifferentiated mechanism to refuse execution. ${ }^{101}$

The departure from the political offense exemption was implemented into German law through $\$ 82$ IRG, which stipulates that the exemption does not apply to circumstances concerning extradition between Member States. ${ }^{102}$ Notwithstanding this, political prosecution-governed by $\$ 6(2)$ IRG - still remains a ground for non-extradition in accordance with Recital 12 of the EAW Framework Decision ${ }^{103}$ and, therefore, is explicitly not mentioned in $₫ 82$ IRG. ${ }^{104}$

\footnotetext{
${ }^{95}$ See Michael Kubiciel, Nomos Rechtshilferecht in Strafsachen $§ 6$, para. 52 (Kai Ambos, Stefan König \& Peter Rackow eds., 2015).

${ }^{96}$ See Schultz, supra note 81, at 625.

${ }^{97} \mathrm{Id}$.

${ }^{98}$ See VOGEL, supra note 82 , at para. 8 .

${ }^{99}$ Art. 5 of the Convention states:

1. For the purposes of applying this Convention, no offence may be regarded by the requested Member State as a political offence, as an offence connected with a political offence or an offence inspired by political motives.

2. Each Member State may, when giving the notification referred to in Article 18(2), declare that it will apply paragraph 1 only in relation to:

a) the offences referred to in Articles 1 and 2 of the European Convention on the Suppression of Terrorism and

b) offences of conspiracy or association - which correspond to the description of behaviour referred to in Article 3 (4) - to commit one or more of the offences referred to in Articles 1 and 2 of the European Convention on the Suppression of Terrorism.

Treaty of European Union on the Fight Against Corruption art. 5.

${ }^{100}$ See Vogel, supra note 82, at para. 8.

${ }^{101}$ See Vennemann, supra note 7 , at 112; VOGEL, supra note 82, at para. 15; MARTin BöSE, GrÜtZNER/PÖtZ/KREß INTERNATIONALER RECHTSHILFEVERKEHR IN STRAFSACHEN $\$ 82$ para. 3 (Claus Kreß ed., 2012); Loïck Benoit, Le mandat d'arrêt européen, in Reve Du MARché Commun ET DE L’Union Euopéenne 106, 109 (2003); see also Thomas Hackner, Schomburg/Lagodny/Gleß/Hackner InTERnationale Rechtshilfe in Strafsachen $\$ 82$, para. 3 (6th ed. 2020).

${ }^{102}$ See HACKNER, supra note 101 , at paras. 1,3 .

${ }^{103}$ Recital 12:

Nothing in this Framework Decision may be interpreted as prohibiting refusal to surrender a person for whom a European arrest warrant has been issued when there are reasons to believe, on the basis of objective elements, that the said arrest warrant has been issued for the purpose of prosecuting or punishing a person on the grounds of his or her sex, race, religion, ethnic origin, nationality, language, political opinions or sexual orientation, or that that person's position may be prejudiced for any of these reasons.

See EAW Framework Decision, supra note 10.

${ }^{104}$ See HACKNER, supra note 101 , at para. 3.
} 


\section{The Continued Necessity for the Exemption Within the European Union}

\section{The Limited Justificatory Force of Mutual Trust and Recognition}

The abolition of the political offense exemption rests on the idea that there is no need for such an exemption within the EU, due to it being a community of shared values — characterized by a high level of protection with respect to the principles of the rule of law-and possessing a common foreign and security policy. ${ }^{105}$ The aforementioned considerations regarding non-interference in the internal affairs of a sovereign state and political expediency are no longer considered appropriate justifications for the political offense exemption, with respect to the relations between Member States, and are deemed to contradict the principle of mutual recognition. ${ }^{106}$ In context with the latter, the abolition is further justified in light of the mutual trust in the judicial systems and full respect for the rule of law, which is legally substantiated by the Member States' obligation to adhere to the basic principles of EU law under Article 6 TEU. ${ }^{107}$ The concept of mutual trust pertains not only to the rule of law of the Member States and the compliance with common basic principles, but also to the current political conditions prevailing within the EU framework. ${ }^{108}$

In both decisions in the matter, the OLG referred to this community of shared values when responding to concerns raised by Puigdemont and his counselors, first and foremost regarding the danger of political prosecution in Spain. With reference to $\$ \$ 82$ and 6(1) IRG, the OLG did not examine the question of whether a surrender could be granted-even though the underlying act was, in fact, a political offense. ${ }^{109}$ Relying on the principles of mutual recognition and mutual trust among the EU Member States, the OLG found that in the common AFSJ, every Member State must presume the adherence to EU law of all other Member States. This is why a breach of the EAW Framework Decision-see Recital 12-can be ruled out. ${ }^{110}$

In its decision of July 12,2018, the OLG formalized and expanded this analysis: The court touched upon the issue that, because the surrender for the "political" offense of rebellion was declared inadmissible beforehand, the political offense exemption was not to be discussed-yet again denying any political dimension to the offense of corruption. ${ }^{111}$ The OLG explicitly deemed the suggestion that the Spanish State, a member of the AFSJ, could abuse criminal proceedings - in order to ultimately punish Puigdemont for his political beliefs or disregard the doctrine of specialty and instigate proceedings on the grounds of rebellion-as "unreasonable" and "unimaginable."112

Notwithstanding the court's decision, the existence of a European consensus on shared values serving as a prerequisite for the abolition of the political offense exemption is questionable, due to the fragility of the community of shared values and the permanent danger of fundamental changes in the judicial and political systems of the Member States. ${ }^{113}$ Accordingly, it cannot be irrevocably assumed that all Member States fully respect the basic principles and adhere to the rule of law. ${ }^{114}$ In this context, it becomes apparent that mutual trust-which is based upon the shared commitment to the basic principles - is fiction, rather than an expression of real trust. ${ }^{115}$ In particular, the

\footnotetext{
${ }^{105}$ See id.; Vervaele, supra note 26 , at 10.

${ }^{106}$ See Joachim Vogel, Abschaffung der Auslieferung? Kritische Anmerkungen zur Reform des Auslieferungsrechts in der Europäischen Union, 19 JURISTENZEITUNG 937, 942 (2001); ECKHART VON BUBNOFF, DER EUROPÄISCHE HAFTBEFEHL: EIN Leitfaden für die Auslieferungspraxis 35 (2005); Pelopidas Andreou, 33 Gegenseitige AnerkenNung von ENTSCHEIDUNGEN IN STRAFSACHEN IN DER EUROPÄISCHEN Union 192-93 (Knut Amelung et al. eds., 2009).

${ }^{107}$ See ANDREOU, supra note 106 , at 44.

${ }^{108}$ See id.

${ }^{109}$ See Judgment of Apr. 5, 2018 at para. 45.

${ }^{110}$ See id. at para. 49.

${ }^{111}$ See Judgment of July 12, 2018 at para. 21.

${ }^{112} I d$.

${ }^{113}$ See SCHOMBURG \& HACKNER, supra note 87 , at para. 3b.

${ }^{114}$ See HACKNER, supra note 101 , at para. 3.

${ }^{115}$ See ANDREOU, supra note 106, at 44; Eva Storskrubb \& Anna Wallerman, Judicial Cooperation in Civil Matters: Coming of Age?, in Routledge Handbook of Justice \& Home Affairs Research 203, 207 (Ariadna Ripoll Servent \& Florian Trauner eds., 2018).
} 
Member States' disapproval of the total abolition of the double criminality requirement-as initially sought by the European Commission - and their mere consent to a softened double criminality requirement ${ }^{116}$ may be considered a sign of the lack of mutual trust which already persisted before the establishment of the EAW. Trust issues have recently been generated by the highly criticized legislative reforms of the justice system in Poland. ${ }^{117}$ The current circumstances in Poland demonstrate the risk of changes to the judicial and political systems of the Member States, which necessarily raise doubts regarding their commitment to the basic principles and the rule of law. As a reaction to the reforms in Poland, the Court of Justice of the European Union (CJEU), although pointing to the significance of mutual trust and mutual recognition in maintaining an area without internal borders, recognized in its judgment of July 25, 2018 the need for safeguards in individual cases. ${ }^{118}$ In particular, the court referred to its previous decision of April 5, 2016 ${ }^{119}$ - wherein it had reiterated that unless one of the grounds for non-execution in the EAW Framework Decision is fulfilled, states are compelled to extradite $^{120}$ _ but, nevertheless, somewhat remarkably recognized that limitations to the principle of mutual trust can be made in exceptional circumstances. ${ }^{121}$ This decision shows that the principle of mutual trust has never been absolute.

It follows from the above-mentioned considerations that the justificatory force of mutual trust and recognition is limited with respect to the abolition of the political offense exemption. Against this background, the abolition is thus not justifiable.

\section{The Exemption as a Means of Attaining a Higher Level of Human Rights Protection}

This lack of justificatory force is highly problematic from a humanitarian point of view. Apart from the principle of non-intervention, the exemption also has to fulfill the demands of human rights. It is meant not only to promote the state's interest but also to protect the requested person, who has a right not to be extradited when he or she faces political persecution in the requesting state. ${ }^{122}$ Where the requested person cannot be expected to be treated "fairly," - that is, in accordance with the principles of the rule of law-the political offense exemption overlaps with the protection from political prosecution. ${ }^{123}$

There is indeed a close connection between the two concepts which justifies treating these offenses divergently. Nonetheless, where the prosecution satisfies the standards of a fair trial, prosecution for a political offense is not political prosecution. ${ }^{124}$ In this sense, many argue that in stable democracies, such as the EU Member States, an undifferentiated refusal by means of the political offense exemption becomes obsolete from a human rights point of view. ${ }^{125}$ As long as protection

\footnotetext{
${ }^{116}$ See HagGenMüller, supra note 6 , at 85.

${ }^{117}$ See Daniel Boffey, EU Hearing Puts Poland in Dock Over Judicial Changes, GuARDian (June 26, 2018, 12:51 PM), https:// www.theguardian.com/world/2018/jun/26/eu-hearing-puts-poland-in-dock-over-judicial-changes.

${ }^{118}$ ECJ, Case C-216/18 PPU, Minister for Justice and Equality, ECLI:EU:C:2018:586 (July 25, 2018), paras. 35-36, 43-45, 79.

${ }^{119}$ ECJ, Joined Cases 404 \& 659/15 PPU, Aranyosi und Căldăraru, ECLI:EU:C:2016:198, para. 80, Judgment of April 5, 2016.

${ }^{120}$ See id. at para. 88 . In a previous decision, the Court had maintained that extradition was mandatory, even if it constitutes a violation of the requesting State's national constitution. See ECJ, Case C-399/11, Melloni v. Ministerio Fiscal, ECLI:EU: C:2013:107 (Feb. 26, 2013), paras. 56 et seq.

${ }^{121}$ See Aranyosi, Cases 404 \& 659/15 PPU at para. 82

${ }^{122}$ See Dietmar Franke, Politisches Delikt und Asylrecht 52 et seq. (1979). Herein lies the dualistic nature of the exemption, which intertwines contrary aspects. Humanitarian considerations, requiring a normative appraisal led by idealistic viewpoints, contrast an objective calculation of the State's best interest. This dualism leads to the exemption being a concept that is hard to grasp and very complex to handle. See VoGEL, supra note 82, at paras. 27-28; see also GILBERT, supra note 49, at 194.

${ }^{123}$ See JANSSON, supra note 82, at 47; VOGEL, supra note 82, at para. 26.; SCHWAIGHOFER, supra note 83, at 109.

${ }^{124}$ See Vogel, supra note 82 , at para. 1.

${ }^{125}$ See id. at para. 28; MEYER, supra note 88, at para. 885; see also Helmut Seitz, Das Europäische Haftbefehlsgesetz, NEUE ZEITSCHRIFT FÜr STRAFRECHT 546, 549 (2004).
} 
from political prosecution is guaranteed, the humanitarian core of the political offense exemption would be maintained. ${ }^{126}$

While it is true that protection could theoretically be attained with the exemption of political prosecution, it is questionable whether the protection is as efficient. As mentioned above, the EU Member States trust in their respective judicial systems, and their recognition of the rule of law implies trust in adherence to human rights. Against this background, it would be a highly delicate matter for a national judge to accuse an otherwise stable democracy of political prosecution in an individual case. It is an emergency brake that is a lot harder to pull, as judges will bear in mind the political consequences of accusing a Member State of political prosecution.

Yet, efficient protection within the EU is pivotal. Contrary to the expectations of the authors of the Framework Decision - and of many legal scholars, who assumed that both exemptions had a quasi-nonexistent scope of application ${ }^{127}$ - the humanitarian aspect of the exemption is relevant even within the EU. ${ }^{128}$ The risk that criminal law might be abused for political prosecution persists, as Member States currently seem to be rediscovering criminal law as a means of settling internal political dispute or for harassing their opponents. ${ }^{129}$

Given the issue at stake, should the level of protection not be set as high as possible? Even if there might not be any competition between legal systems or ideologies ${ }^{130}$ anymore, should there not be a competition for the most protective system? In order to assure the European AFSJ, even doubts regarding the integrity of the criminal proceedings should suffice to shake the trust in the judges' independence and, therefore, to refuse extradition. It is crucial that an individual's rights take precedence over a state's power games. ${ }^{131}$

A high level of human rights protection is equally as important a cause for the EU as mutual trust is - a cause that should not be sacrificed on the altar of mutual recognition. ${ }^{132}$

\section{Negligible Damage to the Principle of Mutual Trust Due to the Low Number of Cases}

There is no denying that the principle of mutual recognition is indispensable for a system such as the EU to function. ${ }^{133}$ Nevertheless, one might question how much damage upholding the political offense exemption within the framework of the European Arrest Warrant would have caused to this principle of EU law. As a matter of fact, many offenses-such as terrorism, which all EU countries indisputably do not consider worthy of protection-were already excluded from the scope of the exemption. ${ }^{134}$ While the exemption is often perceived as a hindrance to judicial

\footnotetext{
${ }^{126}$ See BösE, supra note 101, at para. 4; see also Vogel, supra note 106, at 942.

${ }^{127}$ See BÖsE, supra note 101, at para. 5; Vogel, supra note 106, at 942; Gert Vermeulen \& Wendy De Bondt, Rethinking International Cooperation in Criminal Matters in the EU, 42 INT'L RES. ON CRIM. POL'Y RES. SERIES 233-34 (2012).

${ }^{128}$ See EAW Framework Decision, supra note 10; see infra Subsection D(III)(1); see also SCHOMBURG \& HACKNER, supra note 87 , at paras. $3 a-3 b$.

${ }^{129}$ See Safferling, supra note 3.

${ }^{130}$ See von Weber, supra note 91 , at 169.

${ }^{131}$ See Safferling, supra note 3.

${ }^{132}$ See SCHOMbURG \& HACKNER, supra note 87, at para. 3b; see also Vermeulen \& De Bondt, supra note 127, at 234 (advocating for maintaining such a crucial ground for refusal within the instrumentarium of the EU).

${ }^{133}$ See Aranyosi, Cases 404 \& 659/15 PPU at para. 78:

Both the principle of mutual trust between the Member States and the principle of mutual recognition are, in EU law, of fundamental importance given that they allow an area without internal borders to be created and maintained. More specifically, the principle of mutual trust requires, particularly with regard to the area of freedom, security and justice, each of those States, save in exceptional circumstances, to consider all the other Member States to be complying with EU law and particularly with the fundamental rights recognised by EU law.

${ }^{134}$ All of the offenses listed in Articles 1 and 2 of the European Convention on the Suppression of Terrorism were excluded in Article 5 of the Convention on Extradition between Member States. See European Convention on the Suppression of Terrorism arts. 1-2, Jan. 27, 1977, E.T.S. 90, https://rm.coe.int/16800771b2; Convention Drawn Up on the Basis of Article K.3 of the Treaty on European Union, Relating to Extradition Between the Member States of the European Union, Oct. 23, 1996, 1996 O.J. (C 313) 12; see also SCHWAIGHOFER, supra note 83, at 110.
} 
cooperation among EU Member States, the scope of application is too narrow to cause problems regarding the principle of mutual recognition. ${ }^{135}$ The number of offenses considered "political" has steadily decreased by such perimeters. Yet, the OLG adduces treason as an offense which is internationally considered "political," aimed against the fundamental political order and the continued existence of the state itself. ${ }^{136}$ Puigdemont is thus considered to be a political offender; still, he is the first one to ever be requested under an EAW. Consequently, given that the stakes are high and the number of cases is low, it seems justifiable to deviate from the principle of mutual recognition for political offenses because the damage to the principle is negligible.

\section{Further Narrowing Down as an Alternative Approach to Ensuring the Efficiency of the EAW}

Seemingly, a more sensible approach would be to further curb the notion of political offense instead of abolishing it entirely. ${ }^{137}$ The necessity to do so has been recognized since the establishment of the exemption, ${ }^{138}$ and it was the commonly-followed approach in the twentieth century. ${ }^{139}$

By narrowing down, merely a core of political offenses-which are still closely linked to the specific national legal system and for which a general consensus has not yet been achieved-would continue to fall within the scope of the exemption. In this way, the efficiency of the extradition procedure under the EAW would be ensured. Moreover, political entanglements concerning the EAW would be avoided by keeping the explosive potential of political offenses and the disagreement that still exists regarding certain offenses out of the EAW.

Repealing the exemption has proven too hasty, as Puigdemont's fate illustrates. Spanish Professor of Law, Daniel Sarmiento, maintains that the OLG ruling undermines the EAW's general effectiveness. ${ }^{140}$ Including core political offenses in the EAW discredits the efficiency of the whole instrument, as the EAW cannot be efficient when dealing with such offenses. This becomes evident when taking a closer look at the decision.

\section{The Questionable Suitability of the Formal Procedure of the EAW}

The objective of a more effective and shorter extradition procedure, a principal idea behind the introduction of the EAW, appears to have been adversely affected by the Puigdemont case. The suitability of the procedure, outlined by the EAW Framework Decision, with respect to this case remains questionable. The above-average length of the case documents, ${ }^{141}$ the OLG's failure to meet the deadline, and the detail and elaboration of its assessment are hardly comparable to other, more usual, and less complicated surrender procedures following an EAW. These consequences may derive from the complications of the case, especially with respect to its dimension, ${ }^{142}$ or the sensitive nature of the subject matter. This explains the verbose preliminary remarks in both

\footnotetext{
${ }^{135}$ See also Vermeulen \& De Bondt, supra note 127, at 233-34.

${ }^{136}$ See Judgment of July 12, 2018 at para. 21.

${ }^{137}$ See also Schultz, supra note 81, at 629; SCHWAIGHOFER, supra note 83, at 110.

${ }^{138}$ The so-called Belgian attentat clause-first introduced in 1856 to the Belgian Law of Extradition-excludes the assassination, murder, or poisoning of a head of state or his family members from the scope of the political offense exemption. It quickly found wide reception in international extradition law and particularly targeted anarchist offenses. See JANSSON, supra note 82 , at 86; VOGEL, supra note 82, at para. 6.

${ }^{139}$ See EAW Framework Decision, supra note 10; see infra Section D(II); Schultz, supra note 81, at 625; VoGEL, supra note 82 , at para. 8 .

${ }^{140}$ See Daniel Sarmiento, The Strange (German) Case of Mr. Puigdemont's European Arrest Warrant, VeRFASSUNGSBLOG (Apr. 11, 2018), https://verfassungsblog.de/the-strange-german-case-of-mr-puigdemonts-european-arrest-warrant/.

${ }^{141}$ See Judgment of July 12,2018 at paras. $4-5$.

${ }^{142}$ In the decision the EAW is based on, the Tribunal Supremo charged twenty-five people with various crimes they are said to have committed at different times by different acts. See Judgment of July 12, 2018 at para. 5.
} 
decisions of the OLG. In the court's own words, the case is "durchaus untypisch" (rather unusual), raising doubts about the suitability of the EAW procedure for such exceptional circumstances.

\section{The Importance of Taking into Account National Constitutional Specificities}

The case was beyond the scope of the EAW because the specificity of the national legal systems is particularly pronounced when it comes to political offenses. The conception of these types of offenses is closely linked to a country's constitutional identity. Whether certain conduct is considered an acceptable act of political expression or criminal behavior may vary, depending on the constitutional characteristics of a legal system and a nation's historical experience. ${ }^{143}$ Germany, with regard to its history, has a particular responsibility where purported political offenders are concerned. ${ }^{144}$

Therefore, even within the EU, Member States may not always come to the same moral judgment concerning the legitimacy of politically relevant behavior. ${ }^{145}$ The Puigdemont case, for instance, raised the question whether force was inappropriately used to achieve a political aim. The use of force within democracies is a widely disputed issue among legal scholars. Although, in principle, violence should not be necessary in democracies, some still concede that it can - at times-be justified. ${ }^{146}$ In that sense, Green observes that a state may even acknowledge, as a political offender, an individual requested by a politically sympathetic state. ${ }^{147}$

As political offenses are closely linked to the core values of a society — such as political freedom -it is important that states are able to do justice to their respective constitutional identities, as well as the specific characteristics of their legal systems in this area of law. Therefore, they are not compelled to extradite when specific conduct is not considered worthy of sanctions.

This cause is the idea behind the double criminality requirement. The remaining question is whether the requirement sufficiently enables the states to do justice to their national specificities within the EAW.

\section{The Double Criminality Requirement as an Inadequate Sole Means}

With regard to the Puigdemont case, the examination of the double criminality requirement was a major point of criticism. ${ }^{148}$ After the OLG rendered its decision of July 12, 2018, the investigating judge at the Tribunal Supremo, Pablo Llarena, accused the German court of undermining his ability to act by anticipating the outcome of a trial outside of its jurisdiction. Llarena argued that the OLG's control should have been limited to checking whether the acts described by the Spanish jurisdiction were generally covered by German criminal law, and whether a criminal investigation against the person requested would therefore be justifiable. By passing a final judgment, rather than merely reviewing the abstract requirements for such a prognosis, the OLG did not adequately adhere to the statutory provisions of European law. ${ }^{149}$ Instead, the court chose an approach sometimes referred to as "reinforced double criminality." 150 In order to satisfy this requirement, it is not sufficient that the acts, which are the basis for the charges, constitute a crime in the issuing state, nor that for similar actions, German Law protects similar legal positions. On the contrary, it is

\footnotetext{
${ }^{143}$ See also Ulrich Karpenstein \& Roya Sangi, Der Fall Puigdemont - ein europäisches Problem, VeRFASSUNGSBLOG (Apr. 5, 2018), https://verfassungsblog.de/der-fall-puigdemont-ein-europaeisches-problem/; JANsson, supra note 82, at 232.

${ }^{144}$ See SCHOMBURG \& HACKNER, supra note 87, at para. 3b; Safferling, supra note 3.

${ }^{145}$ See Schünemann, supra note 24 , at 532.

${ }^{146}$ See GILBERT, supra note 49 , at $254-57$.

${ }^{147}$ See Leslie Green, Hijacking, Extradition and Asylum, 22 CHITTY's L.J. 135, 136 (1974).

${ }^{148}$ See Yamuza, supra note 47, at $477-79$.

${ }^{149}$ See El juez del Tribunal Supremo Pablo Llarena rechaza la entrega de Carles Puigdemont solo por el delito de malversación, COMUnicación Poder Jud. (July 19, 2018) [hereinafter Press Release Poder Judicial].

${ }^{150}$ See Yamuza, supra note 47 , at 477.
} 
necessary to imagine that, had the facts of the case occurred in Germany under the same circumstances, they also would have been punishable by means of criminal law. ${ }^{151}$

The OLG judges argued that it was a normatives Tatbestandsmerkmal (normative element of the offense), which thus had to be examined beforehand; however, it was also the only way for the judges to be certain that no conduct would be sanctioned that German law deems valid political opposition.

It must be made clear that Spanish law also requires the use of force. Yet, while the Spanish authorities consider that there are grounds for prosecution, the German judges rule out the use of force $a b$ initio. The conception of the level of force is crucial here. The judges seemingly deemed it necessary to ensure the level of force satisfies the requirements of German law. If one considers that the judges were wrong in their approach to the double criminality requirement, this will imply that one must deduce that double criminality is not an infallible means of protecting the characteristics of the legal system. The judges would, to a very large extent, still be required to rely on the principle of mutual trust by assuming that the two systems are sufficiently compatible in the area, which is not always guaranteed to be the case. ${ }^{152}$

Nevertheless, even if one assumes that the judges did so rightfully and that the requirement is a sufficient means of ensuring that states do not have to extradite for conduct they do not consider illegal, this puts the judges in a very uncomfortable position. The fact that, in a matter as sensitive as political offenses, the judges have the sole responsibility of giving justice to their respective systems seems disproportional. The national judges are thereby placed at the forefront of where mutual trust and constitutional identity collide. The OLG was inevitably going to bear the brunt of the criticism, and it was very well aware of its burdensome task, as the elaborateness and length of the judges' account indicates.

In this context, the OLG attempted to fulfill this responsibility and apparently felt the need to further explain and justify its decision of April 5, 2018 in which it declared the surrender for rebellion inadmissible after facing criticism from German legal scholars. ${ }^{153}$ Therefore, in its decision of July 12,2018 , the OLG not only addressed $\$ 81(1)$ StGB as an offense applicable under German law, but also reviewed $\$ 125(1)$ StGB, and expressly stated that it had taken all StGB provisions into account. It further explained its profound review of the suitability of the force used to achieve success, in accordance with the jurisdiction of the BGH. Having to decide in the context of such political sensitivity is not conducive to a decision free from external influences.

\section{The Remaining Political Dimension of the EAW}

Even though the EAW was meant to depoliticize extradition between Member States, ${ }^{154}$ the Puigdemont case maintained a political dimension. Particularly in Spain, the Catalan situation precipitated serious political conflict, with the emergence of a heated debate provoked by both OLG rulings. In the preface to its second decision, the OLG refers to the seventeen-page account on the historical development of the Catalan independence movement-which was included in the EAW form by the requesting state-as an introduction to the description of the circumstances under which the offense was committed. This unusual approach made it seem as if the Spanish authorities themselves brought a political dimension to the-purely judicial-decision. ${ }^{155}$

Furthermore, Llarena bemoaned an apparent "lack of commitment" to facts that could have destroyed the Spanish constitutional order. ${ }^{156}$ When interpreting this statement, it could be

\footnotetext{
${ }^{151}$ See Judgment of Apr. 5, 2018 at paras. 20-22; Yamuza, supra note 47, at 477-78 (expressing criticism towards this approach, with respect to ECJ jurisprudence in the Grundza case).

${ }^{152}$ See EAW Framework Decision, supra note 10; see infra Subsection D(III)(1).

${ }^{153}$ See Martin Heger, Einige Anmerkungen zum Auslieferungshaftbefehl in der causa "Puigdemont," 5 ZEITSCHRIFT FÜR INTERNATIONALE STRAFRECHTSDOGMATIK 185 (2018).

${ }^{154}$ See EAW Framework Decision, supra note 10; see infra Section B(I).

${ }^{155}$ See Judgment of July 12, 2018 at para. 4.

${ }^{156}$ See Press Release Poder Judicial, supra note 149.
} 
understood either as an attempt to coerce the German courts into taking sides in a purely national political Spanish conflict, or as a reprimand directed at the OLG for interfering with national matters.

However, Llarena has subsequently recanted the EAW against Puigdemont-relinquishing the extradition for the less serious offense of corruption-and has decided not to bring the case before the CJEU, avoiding a confrontation between Germany and Spain at the highest judicial and political levels. ${ }^{157}$ Attempting to de-escalate the conflict between Catalonia and the Spanish central government may well have been a possible objective of the German judges too, bearing in mind the repercussions a criminal trial could have had on the abating but nevertheless ongoing civil upheaval around the Catalan independence movement. On October 14, 2019, violent protests erupted once more in Barcelona, following the sentencing of Catalan separatist leaders pronounced by the Tribunal Supremo. ${ }^{158}$

Puigdemont's case thus reveals that the EAW fails to depoliticize the extradition of political offenders. Such a depoliticization cannot be achieved solely by formally excluding the political granting procedure from the extradition proceedings. The extradition process will always maintain a certain political dimension for as long as the subject matter remains political.

\section{The Exemption as a Means of Promoting the Relationships Among the Member States}

Llarena's reaction is also a fine example of how a non-extradition is often just as much of an intervention into a state's internal affairs as an extradition itself, even though the idea behind the political offense exemption is to avoid intervention by not extraditing. While many argue that the principle of non-intervention is no longer appropriate in a community of shared values and a high level of cooperation such as the EU, ${ }^{159}$ maintaining this exemption within the EU does not, therefore, necessarily mean not intervening in another state's internal affairs. On the contrary, it can be a tool to oppose another Member State's conduct. The necessity of the exemption from a human rights point of view has been described above; however, even with regard to the relationships between the states, the political offense exemption can-at times-be a preferred tool. As a means of political expediency, it avoids having to accuse the requesting state of political prosecution-thereby allowing the refusal of an extradition in a diplomatic manner. ${ }^{160}$ Some deny the necessity of the exemption, arguing that the Member States' relationships are strong enough for them not to have to mask these intentions. ${ }^{161}$ Llarena's reaction, however, illustrates how political offenses can still put a strain on Member States' relationships and the issue could have escalated as far as Spain taking the case to the CJEU. The political offense exemption would allow states to save face. The fact that the judges so firmly ruled out the possibility of political prosecution shows that they were all too aware of the political dynamite they were dealing with.

\section{A Safeguard Against Intervention in Political Conflicts by Means of Criminal Law}

While - from a human rights point of view - the exemption can be a tool for efficient and diplomatic intervention, its main aim is, nevertheless, to remain distant from a state's internal affairs. ${ }^{162}$ The idea behind this non-intervention is, however, not only to avoid complications for the requested state, but - in the light of a state's sovereignty and its right to a political discourse free from external influences-not to interfere in the state's political disputes through the

\footnotetext{
${ }^{157}$ See id.; see also Opinion of Advocate General Szpunar at para. 32, Case C-268/17, Ured za suzbijanje korupcije i organiziranog kriminaliteta v. AY (May 16, 2018) (maintaining that a preliminary ruling on application of the Spanish court would not be applicable to the concrete case by Spanish authorities).

${ }^{158}$ See Violent Clashes Erupt, supra note 79.

${ }^{159}$ See EAW Framework Decision, supra note 10; see infra Subsection D(III)(1).

${ }^{160}$ See EAW Framework Decision, supra note 10; see infra Subsection D(III)(2).

${ }^{161}$ See VogEL, supra note 82, at para. 30; see also Vogel, supra note 106, at 942.

${ }^{162}$ See EAW Framework Decision, supra note 10; see infra Section D(I).
} 
application of criminal law. ${ }^{163}$ Member States should not promote criminal law as a means of domestic political dispute. ${ }^{164}$ Even if a state does not consider the incrimination of certain conduct to be political prosecution, it may not want to condone a certain way of resolving internal conflicts.

How a state wishes to resolve certain internal conflicts is very country-specific. ${ }^{165}$ If the behaviors considered worthy of sanction vary significantly, then the opinions on what the appropriate degree and method of sanctioning should be are likely to differ even more. From an outsider's point of view, it will be extremely delicate to judge whether these reactions are justified because both the historical and constitutional backgrounds play such an important role in the assessment of political offenses.

States should therefore not be forced to take sides in these conflicts. Article 4(2) TEU explicitly cites "ensuring the territorial integrity of the State, maintaining law and order and safeguarding national security" among the "essential state functions." ${ }^{66}$ It appears questionable as to whether EU Member States are obliged to extradite for political offenses and to thereby intervene in the domaine réservé of the requesting state. ${ }^{167}$ This treaty provision was intended to stress that statehood can be preserved and that there are certain essential competences which states do not intend to transfer to the EU. ${ }^{168}$ Where the domaine réservé is concerned, non-intervention does not contradict the principle of mutual trust.

\section{E. Conclusion}

In the present situation, the need for strong cohesion and solidarity between EU Member States has taken on greater significance. Yet, with respect to the recent troublesome developments, it is hardly possible to foreclose the necessity of a political offense exemption-in order for the states to preserve and secure diplomatic and peaceful cooperation-especially in highly sensitive matters of national political importance. The OLG's final decision illustrates both the rift that already exists within the EU and the enduring adherence to the European principle of mutual trust by closing with a-fairly unusual-remark: "The Senate has endeavored to abide by both the provisions of German criminal law as well as European law with its decision. It abundantly trusts that the Spanish judiciary will not act contrarily." 169

\footnotetext{
${ }^{163}$ See EAW Framework Decision, supra note 10; see infra Section D(I).

${ }^{164}$ See Safferling, supra note 3.

${ }^{165}$ See EAW Framework Decision, supra note 10; see infra Subsection D(III)(6).

${ }^{166}$ Art. 4(2) TEU states:

The Union shall respect the equality of Member States before the Treaties as well as their national identities, inherent in their fundamental structures, political and constitutional, inclusive of regional and local self-government. It shall respect their essential State functions, including ensuring the territorial integrity of the State, maintaining law and order and safeguarding national security. In particular, national security remains the sole responsibility of each Member State.

TEU art. 4(2).

${ }^{167}$ See Ulrich Karpenstein \& Roya Sangi, Der Fall Puigdemont - ein europäisches Problem, VerfassungSBLOG (Apr. 5, 2018), https://verfassungsblog.de/der-fall-puigdemont-ein-europaeisches-problem/.

${ }^{168}$ See Adelheid Puttler, Calliess/Ruffert/Puttler EU-Vertrag (Lissabon) art. 4 para. 21 (5th ed. 2016).

${ }^{169}$ Judgment of July 12, 2018 at para. 21.
}

Cite this article: König J, Meichelbeck P, and Puchta M (2021). The Curious Case of Carles Puigdemont-The European Arrest Warrant as an Inadequate Means with Regard to Political Offenses. German Law Journal 22, 256-275. https:// doi.org/10.1017/glj.2021.6 